Special Issue: Green Politics in Germany

Edited by Stephen Milder and Konrad H. Jarausch

INTRODUCTION

Renewing Democracy: The Rise of Green Politics in West Germany

The September 2013 Bundestag election, which reelected Angela Merkel as chancellor, was a clear defeat for the Green Party. Alliance 90/The Greens (henceforth the Greens) fared far better than the Free Democratic Party (FDP), which failed even to score the five percent of the vote required for representation in parliament, but still fell from 10.7 percent to 8.4 percent, losing five of their sixty-eight seats in parliament. Since in March of that same year, surveys had shown their support at 17 percent, this disappointing result forced Jürgen Trittin, the leader of the parliamentary delegation to step down. ${ }^{1}$ In many ways, this perceived electoral debacle marked the end of an era. The former Federal Minister of the Environment, who had originally joined the party in 1980, told reporters that "a new generation" would have to step forward and lead the party into the 2017 campaign. This statement suggested not only that the Greens' rebellious founding impulse was spent, but also that they had become part of the establishment in the Federal Republic of Germany (FRG), now requiring a reinvigoration of their own. Since the Greens were once expected to be little more than a short-lived byproduct of the social conflicts of the 1970s, a closer look at the party's founding moment at the beginning of the 1980s might shed new light on its current predicament.

Though the Greens remain a small party and have been in the opposition throughout most of their time in parliament, their present travails have been linked to a larger crisis of democracy in the FRG. With the Christian Democrats (CDU/CSU) and Social Democratic Party of Germany (SPD) in another grand coalition, the parliamentary delegations of the Greens and the Left Party are all that remains of the opposition. In the eyes of political scientists 
like Franz Walther and Danny Michelsen, the democratic crisis extends far beyond the situation in the Bundestag's plenary hall. Citizens' individualized demands and distance from the official parties, they assert, further challenge liberal democracy in the FRG. ${ }^{2}$ Moreover, the sociologist Wolfgang Streeck has diagnosed "a process of dissolution of the regime of democratic capitalism of the postwar era" for which the Green Party has no convincing answer. Since much of its environmental agenda has been adopted, he sees the challenge as "undoing the institutional damage of four decades of neoliberalism," which can only be achieved through "a break-up of the currency union" of the Euro. ${ }^{3}$ Finally, Ingolfur Blühdorn has lamented "the abdication of the ecologist paradigm" due to the mainstreaming of the Greens who have paid too little attention to the question of sustainability. ${ }^{4}$ While these warnings may be somewhat exaggerated, they suggest that the Green Party's problems are linked to a wider crisis of political legitimation that somewhat resembles the constellation of their founding, which was characterized by leftwing terror attacks and mass antinuclear protests.

The ecological activists, feminists, and pacifists who entered parliament in 1983 considered their project an attempt to renew West German democracy, not to destroy it. Representing a wide spectrum, ranging from the post ' 68 left to rightwing conservationists, this colorful movement brought an antiauthoritarian style to German politics that suggested change was possible. Its followers were mostly college-educated white-collar professionals of the younger generation, tired of the materialism of their successful postwar elders. The unlikely alliance made history when it won seats in parliament with 5.7 percent of the vote in 1983, and entered into a short-lived RedGreen coalition government in the state of Hesse in 1985. Due to their opposition to German unification, the Western Greens failed to gain the required votes for Bundestag representation in 1990, but were rescued by their East German partners, the dissidents of Alliance 90 (Bündnis 90), who were elected via a special regional dispensation applicable to that election only. Recovering their support, they re-entered the Bundestag in 1994, and, in 1998, the Greens were finally able to assume the reins of government with Joschka Fischer as Foreign Minister with the help of their Social Democratic senior partner under Chancellor Gerhard Schröder. ${ }^{5}$ Buoyed by protests against the building of a new central train station in Stuttgart, the Greens were even able to take over the premiership of Baden-Württemberg in 2011.

Since an entire generation has already elapsed since the Green Party's founding, the trajectory of its initial formation, rise to power, and recent frustration begs for a critical historicization. Due to the increasing temporal distance and greater availability of primary sources on its origins, the 
party's evolution that was until quite recently the domain of the social sciences has now started to become a topic for a "history of the present." ${ }^{6}$ Originating in the controversy over the interpretation of the Third Reich between Martin Broszat and Saul Friedlander, the concept of historicization simply means treating a subject as if it were no longer a part of current events but rather something from the past, amenable to historical research. The adjective "critical" was added to the term in order to indicate that the historicization of the Third Reich was not meant to diminish its atrocities, but rather to analyze them in their temporal setting instead of treating them as part of an eternal present. Thus, historicizing the Green Party means recognizing its surprising founding and complicated development as a process that occurred in a different time and ought to be explored from an historical perspective, even if the Green Party is very much alive in the current political debates. ${ }^{7}$

While building on the existing social science literature, this special issue therefore intends to provide a historical perspective on the development of the Green Party by focusing on five key themes. First, the contributions analyze the scholarly literature on the rise and development of the environmental movement in West Germany. Second, the chapters address the emergence of the Green Party within the broader context of the "soft caesura" of the "transformation of politics" during the 1970s and 1980s. Third, the articles discuss the debate about the new social movements (NSM) in order to determine in what way the Greens were an attempt to institutionalize them. Fourth, the essays take a brief look at the parliamentary record of the Greens as an "anti-party party." Finally, the papers ponder the contribution of the Greens to the more general process of liberalization of the Federal Republic. ${ }^{8}$ The editors hope that such a temporal perspective will help make some of the present conflicts and challenges of the Green Party more transparent.

\section{Historical Approaches}

The emergence of the Greens attracted considerable scholarly attention even before they entered the Bundestag. Initial assessments like Lilian Klotzsch and Richard Stöss's ninety-page entry on the party in Stöss's 1983 Parteien Handbuch or Anna Hallensleben's 1984 monograph on the creation of the Green Party of Lower Saxony painstakingly untangled the Greens' disparate roots in a conglomeration of various minor parties. ${ }^{9}$ These first studies offered a clearer understanding of the Green Party's immediate 
institutional history than many later works. Moreover, they revealed the extent to which the formation of a new political party with a real chance of entering parliament marked an important break with "politics as usual" in the eyes of contemporary observers. Due to the Greens' small parliamentary delegation, not to mention the widespread expectation that they were little more than a passing fad, the nature and the significance of this electoral turning point, however, remained unclear.

Extending into the early 1990s, another wave of studies by political scientists like Herbert Kitschelt and Andrei S. Markovits interpreted the rise of the Greens as part of the political changes that transformed the European Left. Kitschelt's 1989 study The Logics of Party Formation used quantitative analysis to define the green parties of northwestern Europe as "left-libertarian" because they coupled a commitment to social justice with distrust of centralized authority. ${ }^{10}$ Markovits and Philip Gorski's important 1993 monograph, The German Left: Red Green, and Beyond, asserted the "greening" of the formerly "red" Left." They viewed the Greens as the descendants of dissidents who left the SPD after 1959 and who, by the 1980s, had re-directed the Left towards a set of new issues and a new political orientation devoted to protecting the most vulnerable members of society. ${ }^{12}$ By focusing on the Greens' part in the changes to the Left's character of the Left, these studies opened up important questions about wider political and social changes, as well.

Margit Mayer and John Ely's 1998 volume The German Greens: Paradox between Movement and Party took an important step towards historicizing the Greens by looking at their transformation from protest movement to political party after they entered parliament. ${ }^{13}$ Published shortly after the Greens' 1990 election debacle but prior to their time in government, Mayer and Ely's volume continued to see the Greens as a paradoxical political formation, foreign to established parliamentary politics. Other scholars sought to classify the heterogeneous Greens in ideological terms. Though much ink has been spilled about the conflicts between "realos" and "fundis," most authors have placed the Greens on the political Left. While Joachim Raschke catalogues the Greens' various factions, he argues that "the party as a whole, not just a specific current, is to be classified as left-ecological." In fact, on a diagram of German political parties from left to right, the Greens are placed significantly further left than the SPD. ${ }^{14}$

Recent developments have given cause to reconsider the validity of the Greens' self-description as "neither left, nor right, but ahead" (weder links noch rechts, sondern vorn). The success of the conservative Winfried Kretschmann in Baden-Württemberg, journalistic speculations about a Black-Green coalition at the federal level and the new Chairman Cem Özdemir's deter- 
mination to take up the FDP's mantle as the party of individual liberties have drawn attention to less radical dimensions of the Greens. ${ }^{15}$ Silke Mende's comprehensive 2011 study, which argues that various currents that flowed together late in the 1970s to form the "founding Greens," therefore represents an important advance in the historiography. ${ }^{16}$ Mende explains the ways in which not only leftists but also conservatives of various stripes played an important part in shaping the Green project during the late 1970s and early 1980s. In so doing, she shows how such disparate tendencies could co-exist within the same party, and thus opens the door to consideration of the Greens as a model for the sort of "post-ideological politics" that Belinda Davis argues has emerged since the 1970s in her contribution to this special issue.

Other commentators on contemporary German politics reconsider the Greens' place within German society as a whole. Markovits explains this relationship succinctly by claiming that the Greens' entrance into the Bundestag was also their entry into the West German establishment. Describing the Greens as "quintessential representatives of the European counterculture," he and his co-author Joseph Klaver argue that since 1983, they have "successfully institutionalized in Germany's mainstream a brand of progressive politics that thirty years ago was at best a fringe phenomenon consumed and followed by politically marginal sects." In his 2007 book, Joschka Fischer and the Making of the Berlin Republic, Paul Hockenos similarly places the Greens at the heart of the important political developments that led to the creation of a peaceful, democratic, and reunited Germany. ${ }^{17}$ Far from seeing them as noteworthy but inexplicably "paradoxical," Hockenos asserts that the Greens made an essential contribution to the democratization of united Germany.

More recently, Edgar Wolfrum's impressive 2013 study of the Red-Green coalition under Chancellor Schröder describes the Greens' first foray into government at the national level. His emphasis on the split between fundamentalists and pragmatists in Rot-Grün an der Macht enmeshes the Greens' history into the Federal Republic's process of becoming a normal national state. ${ }^{18}$ Wolfrum emphasizes the transformative effects of the changes-from the Harz IV welfare reform to the first Bundeswehr deployment-that the Schröder-Fischer government was compelled to authorize. While these decisions cannot be attributed primarily to the Greens, they made them "a key party in the political landscape of the Federal Republic" because they could "enter coalitions with the Left and the Right." In his impressive synthesis, Ulrich Herbert clearly links the Greens and their brand of generational protest politics to the larger trajectory of expanding participation and 
liberalization of the political culture in the Federal Republic. ${ }^{19}$ Not only are the Greens starting to appear in histories of the Federal Republic, their contributions are also considered essential for the broadening of participation in its democracy.

One of the tasks of future research, then, is to investigate the Greens' relationship to these developments in order to ascertain more clearly their role as a product or promoter of Germany's transformation. Their sudden rise in the late 1970s and their disproportionate influence thereafter were made possible by a more general transformation of politics in terms of values, life-styles, and involvement. Frank Bösch sees the shift from conventional parties towards networks, mobilization, and postmaterialism as a media-driven process that affected the entire political spectrum..$^{20}$ By looking more closely at the emergence of green politics within a broader context, the papers assembled here show that widespread identification with green concerns is evidence not only of the Greens' own influence since 1983, but also of a series of changes since the 1970s that have made German society as a whole more open to new issues and democratic participation.

\section{The 1970 as Soft Caesura}

Thinking about the ways that the Greens have been involved in the democratization and normalization of the Federal Republic requires placing the party's emergence into the rapidly developing historiography of the 1970s and 1980s. The Greens' rise, in other words, must be considered alongside other important questions of contemporary history such as value change, the shock of globalization, and the changing nature of democracy and representation. The essays in this special issue show how the Greens' development over the longer term fits into the emerging consensus that the turbulent 1970s mark not so much a "crisis" in and of themselves as a time in "which the seeds of future crises were sown." ${ }^{21}$ In the sense that the Greens formed late in the 1970s and arguably made their most significant contributions to German society, policy, and democracy in the last fifteen years, understanding the 1970s as a "soft caesura" that triggered many of the problems of the present, helps illuminate the Greens' place in this transformation. ${ }^{22}$

The significance of the soft caesura approach is perhaps most readily apparent in the debate over the socioeconomic changes that occurred throughout Europe and the West since the end of the postwar boom. ${ }^{23}$ The first interpretations equated them with the emergence of a wholly new "post-industrial" society. ${ }^{24}$ Already in 1969, the French sociologist Alain 
Touraine described the emergent postindustrial society as one in which "economic decisions and struggles no longer possess either the autonomy or the central importance they had in an earlier society." Though he acknowledged that postindustrial society is "more 'driven' by economic growth than any other [type of society]," Touraine's insistence that postindustrial society was wholly new and was dominated by problems of alienation rather than exploitation downplayed the persistence of problems linked to industrial society. ${ }^{25}$ Yet, debates over off- and on-shoring are a stark reminder that economic decisions and struggles retain a central role in German and European society even if other issues have gained in prominence. A soft caesura approach, drawing on Peter Stearns' conception of a third industrial revolution, suggests that problems of industrial production continue to co-exist with the alienation that Touraine saw as central to postindustrial society. ${ }^{26}$

The soft caesura perspective also informs recent studies of politics and ideologies by scholars like Belinda Davis. Whereas Daniel Bell heralded an "end of ideology" as early as 1960, these new analyses broaden our understanding of the way that politics are now conducted. ${ }^{27}$ Davis's concept of "popular politics," points to the importance of "manifestations of political expression" that occur "outside of formal channels and involv[e] broad populations." 28 By arguing that such acts of expression have "confronted the prevailing limits of legitimate political participation, and served more broadly to redefine 'politics' and democratic participation," Davis makes room for meaningful politics outside established structures and beyond the traditional left-right divide. ${ }^{29}$ Yet, Davis's conception of the emergence of popular politics should not be seen as a hard break. Indeed, Forging Democracy, Geoff Eley's authoritative history of the European Left since 1850 calls the expansion of democracy the essential focus of leftist politics over the past 150 years. ${ }^{30}$ In essence, Davis is describing how that project of democratization has been continued by other means in the postwar period, and particularly since 1968 .

Samuel Moyn's description of the growing importance achieved by "human rights" as an ideology "bound up with the widespread desire to drop utopia and have one anyway" suggests a more pessimistic reading of postwar political developments. Because human rights advocates are concerned with individual rights rather than the collective good, the replacement of the twentieth century's "grand political visions" by human rights suggests a withering away of collective politics, not unlike that asserted by other critics of activism after 1968. Nevertheless, by seeing human rights as the latest in a series of desired utopias, and as "a motivating ideology in the 
confusing tumult of 1970s social movements," he offers the concept as a unifying idea within the framework of heterogeneous, postideological politics. ${ }^{31}$ In effect, Davis and Moyn are describing the same sort of change from different perspectives. While Moyn sees the adoption of "human rights" rhetoric as tantamount to a retreat from politics, Davis presents "popular politics" as a powerful means of continuing the struggle to expand democracy that is not weighed down by the baggage of earlier ideologies. The Greens' represent an important case in point because the efficacy and direction of their "postideological" politics are a matter of considerable dispute. ${ }^{32}$ Indeed, untangling the extent to which Green politics are a means of carrying forward the struggle to expand democracy is an important objective for research aimed at understanding contemporary politics.

Perhaps unsurprisingly, the same sort of soft change has been registered by historians focused on the Greens' marquee issue-environmental affairs. Michael Bess has made this point most clearly in his aptly titled The LightGreen Society, which studies French attitudes towards the environment in the postwar period. While Bess notes the emergence of an overwhelming rhetoric of environmental concern since the 1970s, he concludes that French society remains merely "light-green," since the French have not fully devoted themselves to environmentalism in practice despite their powerful rhetoric. ${ }^{33}$ Similarly, the leading environmental historian J.R. McNeill concludes an essay on the global environmental movement since the 1970s by pointing out that while environmental concerns seem to flourish in the "anxiety vacuum" that results "when security seems assured and the economic pie is growing," they recede from focus at other times. He concludes that only an environmental catastrophe has the power to really focus concern on environmental issues. ${ }^{34}$

Frank Uekötter emphasizes that even in Germany, home to Mülltrennung and the Energiewende, it is important to keep in mind the distinction between Bess' "light green" society and a "deep green" commitment to the environment, which would require radical changes to society and the economy. The fact that all of the FRG's major parties have adopted some environmental values and even promoted various reforms, but no fundamental transformation of German society is in sight, suggests that environmental protection can be considered as devoid of a grand political vision as human rights. While Markovits and Klaver's contribution to the present issue makes clear the global salience of what they have deemed the "Green brand," their essay, too, implicitly points out the tension between identification with environmental ideas on the one hand, and the incomplete adoption of ecological practices on the other. ${ }^{35}$ 
Another area of necessary research is therefore this discrepancy between the breadth and depth of environmentalism, which has been a core issue for the development of Green politics since the 1970s. Even as environmental protection has become increasingly accepted across the German political spectrum, the deep ecology of the Greens' "fundi" wing has disappeared from politics altogether. The result seems to be an environmentalism that is omnipresent, but moderate and often devoid of significant social and economic consequences. It still needs to be explained how general environmental concern has spread since the 1970s through the media, social networking, and protest actions, becoming a social consensus that in moments of drama like the 2011 Fukushima nuclear accident in Japan could induce a conservative-liberal coalition to adopt a policy of shutting down nuclear power. How is it possible that at the same time German society remains in strict opposition to speed limits on the Autobahn?

\section{New Social Movements}

For quite some time scholars have placed the Greens' roots in the context of the so-called new social movements of the 1970s. Markovits and Gorski perhaps best articulate this conception of the Greens' family tree in The German Left. Their account traces the party's genealogy from dissenters who left the Social Democratic Party after the passage of the moderate Godesberg Program in 1959 and the exclusion of the radical youth organization Sozialistischer Deutscher Studentenbund (SDS) in 1961, to the student movement, and finally to the new social movements of the 1970s. From these movements, they argue, emerged the local- and state-level Green electoral lists that immediately preceded the formation of a united Green Party at the federal level. ${ }^{36}$

Political developments in the 1970s play a pivotal part in this conception of the Greens' history, due particularly to its close focus on the Left. For youthful activists, the dissolution of the SDS in 1970 induced a widespread malaise that led to a further splintering of the movement. While some activists famously turned to "lifestyle" issues, others devoted their energy to the formation of dogmatic and ideologically narrow Communist parties (the so-called "K-Groups"). ${ }^{37}$ The moderate reformers returned to the SPD, while yet other groups participated in the new social movements. The smallest yet best known faction turned to political violence, forming the Red Army Faction and other terrorist groups. ${ }^{38}$ This divergence of political styles and approaches-frequently juxtaposed to the supposedly monolithic socialist 
"Old Left"-caused both 1970s activists and later scholars to ponder what had become of "the Left." The Greens' emergence at the end of the decade, and the entrance of hardliners from the K-Groups, alternative lifestyle activists, and SPD dissidents into the party once again allowed green politics to become synonymous with leftist politics.

The present issue reconsiders this widespread theory of the Greens' rise that links the party so closely with the Left. The term new social movements is typically considered to comprise a set of "single-issues movements" including the women's movement, the peace movement, and the environmental movement, among others. More recent research, however, has begun to take more seriously the links between these various movements in terms of both political concerns and personnel. Stephen Milder's contribution, for example, explains how even at the grassroots level, anti-nuclear protesters-many of whom were political conservatives and CDU supporters-closely associated their concerns about nuclear energy with economic issues and democracy matters. He also shows how local antinuclear protests brought together people from across the political spectrum and from different parts of society on the basis of these sorts of widespread and adaptable concerns. ${ }^{39}$

Belinda Davis also explores the relationship between the new social movements' internal heterogeneity and the founding of the West German Greens. She follows the biographies of individual activists, particularly those who came from the earlier "New Left," in order to provide evidence of their concerns about many different issues and the ways that they conceived of their activism-whether primarily directed at environmental affairs, peace, or women's rights-as a means of addressing a larger set of interconnected issues. Thus, Davis posits an important transformation in these activists' thinking that occurred after the dissolution of the student movement and before the formation of the Greens, calling it somewhat surprisingly an "anti-ideological" politics. Although Davis shows clear links in terms of personnel between the student movement and the "founding Greens," she also sees these as two significantly different projects. The Greens are not simply a continuation of the West German New Left by other means, but rather their very emergence is an invitation to rethink the meaning of the Left-Right divide in contemporary politics.

Finally, Sarah Summers explores the impact of the new feminism on the Greens, which is omnipresent in the party's appearance but all too rarely examined. The frustration of activists with the only modest responsiveness of the parliamentary process to women's concerns pushed many feminists into a more radical autonomous activism. Their encounter groups, bookshops, Kinderläden, and safe houses created an infrastructure populated by 
committed individuals who were often also concerned about the degradation of the environment or fearful of nuclear war. ${ }^{40}$ As a result many of the early Greens were feminists, and the party was the first to insist on complete parity of leadership and Bundestag representation. It was no accident that the first charismatic leader of the party was a woman, namely Petra Kelly. Once again, the feminist project was highly political, but its agenda cut across the established divisions in the party politics of the Federal Republic.

Taken together, these contributions on the new social movements of the 1970s raise new research questions on the ways in which the NSMs served as a site for the rethinking of ideologies and the formulation of new modes of political praxis. They emphasize the heterogeneity of movements that included veterans of the student revolt, as well as rural vintners, and that could draw on their protagonists' practical concerns about their livelihoods, as well as their will to change the world. Perhaps most poignantly, these contributions reveal a bitter disenchantment with established political parties and with "politics as usual." By doubting governing politicians and established political practices rather than rejecting them outright, NSM activists created a new space only partially outside liberal democracy within which Green politics were able to develop.

\section{The Anti-Party Party}

It was precisely such a sweeping rethinking of political means and ends that allowed for the formation of the Green Party from a wide cross-section of activist groups, pre-existing minor parties, and concerned citizens at decade's end. Nevertheless, this convergence was more than simply an alliance of convenience, engineered to overcome German electoral law's "five percent hurdle." Instead, a shared set of political values and common concerns about the direction of German society allowed for meaningful political cooperation between diverse groupings and actors. In this sense, it is necessary to see beyond the presumed left-right divide in order to understand the Greens' formation and their place within the changing political landscape. Similarly, while the Greens clearly had their doubts about the entire system of parliamentary politics, their approach to participating in electoral campaigns revealed a deep-seated commitment to grassroots democracy. At bottom, in other words, the Greens' had both a collective vision and a collective approach to politics.

In her contribution, Silke Mende explains how such a heterogeneous spectrum of people and groups came together in opposition to West Ger- 
many's postwar consensus, but in-line with the broader changes taking place across the Federal Republic during the 1970s. "The early German Greens were deeply convinced that new questions and challenges needed new political answers that moved beyond traditional categories and apparently antiquated ideas." Mende insightfully identifies the common core of the Greens' approach to politics-a commonality that has too frequently been overlooked by previous scholars focused on ideological differences precisely because it is alien to traditional political categories and ideas. ${ }^{41}$

The notion that the Greens' convergence marked the emergence of a new politics was tested as soon as they entered the Bundestag, where they encountered the West German political establishment. Mende's article follows the Greens through this transition, revealing how the party adapted to the Bundestag, but also how it engendered new approaches to important political topics, particularly integration, as well as social and labor policy. Most importantly, however, she sees the Greens as initiating changes to political praxis within the Bundestag, reflecting the formation and actions of the new social movements during the 1970s. First, the party's emergence was a product of a changing conception of the political that allowed for collaboration across presumed cleavages. Second, the Greens' position in parliament, even as a minor opposition party, allowed them to articulate this shift in political style within the Bundestag, and thus to attempt to bring changes that had emerged at the grassroots to bear on high politics.

Focused on the career of the Greens' leading figure during the early 1980s, Saskia Richter's contribution on Petra Kelly reinforces the stark difference between Green politics outside and within the Bundestag. Richter shows how Kelly herself emerged as a party leader between 1980 and 1983 due to her links with the NSMs in the Federal Republic as well as her international contacts. Yet, after entering parliament, Kelly quickly found herself "without basis in the Bundestag." Thus, Kelly's biography helps to reveal the importance of the Greens' adaptation to the conditions in which they had to act in parliament, and also the extent to which the ways of doing politics that developed out of the movements of the 1970s could not always stand up to the challenges of working within the structures of parliamentary democracy. ${ }^{42}$

Friederike Brühöfener's essay on the peace movement suggests that the Greens' entrance into parliament did not mean the end of the new social movements. In fact, as she shows, the peace movement itself continued to gain support and to take an ever-greater role not just in politics but also in German lives during the early 1980s. Brühöfener's emphasis on the debate over nuclear fear and the broader politics of emotion that accompanied the 
peace movement reveals how the same sort of diverse coalitions of activists, including many neophytes to public protest, came together around a new approach to an old concern. In so doing, they too initiated further changes to political praxis through their activism. That an "emotional" version of politics could be considered to have the potential to bring down West German democracy emphasizes the extent to which such new approaches confronted the existing political system, which was premised on a formalistic version of liberal democracy. ${ }^{43}$

These contributions, which span the early 1980s covering both the Greens' entrance into parliament and the new social movements that remained outside of the Bundestag, illustrate the Greens' relationship to activism and the political changes of the 1970s and 1980s. While the party's formation can be seen as one product of a larger shift in politics and mentalities that occurred throughout the 1970s, its entrance into parliament and its advocacy work within the Bundestag ought to be understood as catalysts of further political changes. Both were propelled by the concurrent development of the peace movement, which generated a new sort of politics with mass appeal during the early $1980 \mathrm{~s} .{ }^{44}$ At the same time, however, the failure of either the Greens or the NSMs to radically change democratic institutions or to destabilize West German democracy suggests that their novel approach actually had a rather limited effect on the established political system. Yet, the Greens' indirect and long-term impact on the style and agenda of politics raises the question of how significant these transformative impulses turned out to be, and, specifically, if they contributed more to social disaggregation and the ascendancy of neoliberalism or to the shaping of a new collective form of participation.

\section{The Impact of the Greens}

In their contribution to this collection, Andrei S. Markovits and Joseph Klaver attribute to the Greens an impressive agenda-setting role in the transformation of West German society, which they describe by reviewing the four pillars of Green politics. The Greens' environmentalism, they argue, has led to Germany's nuclear phase-out and made pro-environmental rhetoric a necessity for politicians from every party. Their feminism has dramatically increased the number of female parliamentarians and has even begun to bring more gender balance to corporate boardrooms. Their advocacy of peace and nonviolence is also readily recognizable in a German state that has rarely committed Bundeswehr troops to international missions. Finally, 
while they admit that the Greens' concept of grassroots democracy has been changed since they first entered the Bundestag and began adapting to parliamentary work, Markovits and Klaver find that the Greens have sought to promote a more informal style and blaze a more participatory path.

The other contributions to this collection, which are focused on the Greens' emergence during the late 1970s and early 1980s, also shed some light on the later development of green politics and their relationship to democratic praxis. Significantly, they highlight the dynamics by which the important changes to German society and to the Greens themselves were effected. They are a reminder that when the Greens first entered the Bundestag in 1983, they caused concern across the Federal Republic. Already during the campaign, Der Spiegel had confronted Green Party co-chair Rainer Trampert with allegations that the Greens would make the Federal Republic "ungovernable." 45 This concern extended even to the United States, where Reagan administration officials voiced fears that the Greens would destabilize NATO. ${ }^{46}$ Yet, the German media quickly realized that this concern was misplaced; the Greens would have little real power in parliament. By the summer of 1983, most domestic reports on the new Fraktion discussed whether or not it would be able to uphold its pledge to conduct itself as a truly "new" party within the Bundestag, not the extent to which it might upend German democracy. ${ }^{47}$

Both Mende and Richter's contributions to this collection show the Greens' difficult process of adaptation to parliamentary routine, and assert that they did little that might have caused the FRG to become ungovernable. In fact, Petra Kelly's idea of the "Anti-Party Party"-perhaps the most radical vision for Green politics in parliament-was quickly jettisoned by the Greens. Though Kelly continued to act in accordance with this notion, neither she nor her ideas gained much traction in parliament. Instead, it seems that the Greens succeeded in accomplishing just the opposite. Rather than destabilizing the parliamentary order, their inclusion of extra-parliamentary protest was ultimately able to reinforce it, as Mende demonstrates. Their presence allowed citizens who had previously not identified with parliament to feel represented. ${ }^{48}$ Their new approaches to a range of issues influenced the political agenda, changing the debate on topics from integration to social welfare, not to mention the environment. With time, as Edgar Wolfrum shows in Rot-Grün an der Macht, these same issues became central to the Schröder government's program and led to the Federal Republic's evolution into a more normal nation state in the 2000s. ${ }^{49}$

It is, nonetheless, important to question this triumphalist narrative. First and foremost, the miniscule Green Bundestag delegation-28 of 520 
deputies after the 1983 election; 44 of 519 after 1987- certainly cannot be credited with making such sweeping changes on its own. In fact, the Greens' aloof and poorly orchestrated 1990 Bundestag campaign only showed their talent for misunderstanding historical events and making themselves irrelevant. Conducted under the motto "Everyone is talking about reunification, but we're talking about the weather!" the Greens' postnational campaign failed to take seriously the emotional power of the popular desire for reunification. As a result, the Greens lost almost all of their seats in parliament and left themselves with little ability to shape the initial decisions of the reunified Federal Republic. In the eyes of many observers, this crisis raised serious questions about the Greens' future. ${ }^{50}$

In fact, the Greens learned a great deal from the 1990 election debacle and determined to take a more professional approach to the 1994 campaign. Their efforts quickly paid off, as the party returned to its previous strength in 1994 (49 of 672 seats) and became junior partner to the SPD in the federal government as a result of the 1998 election. On the one hand, the Greens' "professionalization" unleashed a torrent of criticisms from dissident members as well as scholarly pundits, alleging that the Greens had become an establishment party like any other without any potential to change German society. ${ }^{51}$ On the other, more sympathetic politicians and scholarly admirers celebrated this same transformation, arguing that the Greens succeeded in significantly changing German politics and society through their integration. Markovits's and Klaver's essay on the success of the "Green brand" is a particularly pithy version of this narrative. ${ }^{52}$ While there is a clear divergence between these two camps on what the Greens have achieved until now, they seem to be agreed that the Greens have adapted themselves to liberal democracy to such an extent that there is no reason to suspect that they will strive for radical change and forge a wholly new, participatory democracy in the FRG.

Instead, one might even wonder whether the Greens' "new" approach to politics did not make an unwitting contribution to the political changes that ushered in neoliberalism throughout Europe, which purportedly have given rise to what Colin Crouch calls "post-democracy." As a small but diverse party concerned with a myriad of individual interests, the Greens helped to diminish the appeal of the SPD, the unified mass party of the working class and its trade unions. Their pursuit of a self-centered cultural individualism could be considered akin to the individualistic profit orientation of economic neoliberalism. In this regard, they seem evidence of Crouch's assertion that the diverse and heterogeneous classes and groups that comprise most of society are incapable of coming together in the name of a collec- 
tive, class-based interest as the working class once $\operatorname{did} .^{53}$ It is in regard to their place in post-democracy that the Greens' emergence and early history is perhaps most informative. Understanding the extent to which the new party's formation was an improbable project, carried out by a diverse group of activists who were deeply committed to coalition politics and to liberal democracy helps us to see that there is potential for civic engagement and collective interest formation in contemporary societies.

Quite to the contrary, the Greens' own deployment of individual interests towards their environmental, democratic, and social goals may help to explain why the German reorientation of the 1980s remained more limited than the neoliberal shift in the Anglo-American public. Whereas in the United Kingdom and the United States Thatcherism and the Reagan Revolution radically transformed politics in the 1980s, Helmut Kohl's geistigmoralische Wende (spiritual moral turn-around) did not change the Federal Republic to nearly the same extent. ${ }^{54}$ Far from being a true "turnaround" for German society, Kohl's policies left the status quo largely intact, forcing the Red-Green government to take up issues like unemployment reform after his sixteen-year tenure in office ended in 1998. As they disagreed with those advocating neoliberal approaches to most policy issues, the Greens' rise and the changes to German society they helped to bring about can at most be associated with its milder German variant. Having helped to bring about a more moderate neoliberalism may not sound like a particularly proud achievement, but the Greens' role in politics and their larger goals help us to think about the potential for a more inclusive politics in a postdemocratic age. A final set of questions therefore concerns the Greens' contradictory role in the erosion or renewal of democracy.

\section{The Challenge of Historicization}

By placing the Greens into the political transformations of the last forty years, this collection intends to reinforce the historicization of green scholarship by raising important questions that have yet to be fully addressed. These issues concern several areas of interest. First, the Greens' relationship to the Left and the meaning of the new political forms that they promoted must be further studied. Second, and closely related to this first point, the role of Green politics as an ideological response to the end of "classical modernity" must be further explored. Third, the globalization of protest movements suggests that the internationalism of Green politics also ought to be analyzed more systematically. Finally, the success narrative that char- 
acterizes many of the contributions to this volume must itself be questioned. Have the Greens truly "democratized German democracy?" In light of the copious recent works by political scientists that detail the dire state of contemporary democracy, this seems a particularly hard case to make. Yet, by returning to the Greens' origins in the 1970s, the essays included in this collection suggest that a historical perspective can tease out to what extent the Green project contributed to the emergence of "post-democracy" and to what extent the Green Party represents a potential means of conducting meaningful politics within a mass-democratic society. ${ }^{55}$

Since the Greens tend to be considered "of the Left," questions about their place within that camp and their significance for leftwing politics are important subjects for further study as well. The research presented in this collection shows that the Greens' new approach to politics drew on a wide range of influences, many of which went beyond the traditional Left. Moreover, their recent maneuvering also suggests some potential affinity for a conservationist brand of conservatism, which can also be traced to their diverse roots. Nevertheless, the Green project of significantly changing society has to be considered as the possible replacement of the fragmented and confused Left of the post 1968 era. And yet, if by becoming more moderate the Greens have contributed to the normalization of the Federal Republic since reunification, then it may be time to start searching for the radical Left's heirs elsewhere. This debate is particularly important in light of the crisis of socialism that occurred in the past several decades. ${ }^{56}$ If the Greens represent one dimension of that transformation of politics, then one must ask: what is the potential of such anti-ideological politics for further reform?

The controversy about the Greens' place within the Federal Republic raises another set of important questions about their relationship to classical modernity. In many ways the antinuclear protests from which the Greens emerged were also a rejection of the soulless character of modernization as represented by the machines and organizations of the second stage of the industrial revolution. Rejecting the dominance of the automobile, disliking the cement desert of skyscrapers and disparaging the material greed of capitalism, many Green activists sought to return to a simpler life and therefore went back to the countryside. Nevertheless, the Greens were also quick to embrace the Internet for the sake of organization and to develop technologies that would maximize renewable energy through solar and wind generation instead of consuming finite fossil fuels. Rather than ridiculing the Greens as a neoromantic, antimodernist impulse, scholars might want to think more seriously about their search for an "alternative modernity" that 
would not escape from but rather redirect the dynamic forces of high technology and capitalist competition into a more humane direction. ${ }^{57}$

Due to the global nature of environmental concerns, the transnational connections between protest movements and green parties also should be analyzed further. Recent research has begun to explore the transnational connections of the generational revolt of the late $1960 \mathrm{~s} .{ }^{58}$ But, the comparative dimension that was important for a number of early studies of the Greens as a European phenomenon, such as Kitschelt's Logics of Party Formation, has fallen by the wayside in most recent works. ${ }^{59}$ Nonetheless, activists throughout Europe and beyond have frequently referenced the German Greens' very prominence as a driving force behind their own projects, particularly in their attempts to enter electoral politics. However, their conflicted relationship with East Germany, detailed in Regina Wick's new book on the Greens' Deutschlandpolitik, raises additional questions about the nature of their internationalism, which appears to be more statist-and more accepting of established institutions-than one might think..$^{60}$ Thus, putting the German Greens into a transnational context is important for understanding the Greens' relationship to the globalization of anticapitalist protest since the 1970s.

Finally, the Greens' achievements in the field of democratization, the major focus of the present collection, must also be the subject of further study. The Green case offers an important new perspective on narratives of German history since 1945 that center on the FRG's "democratization" or "liberalization." What does the rise of a grassroots movement that challenged established parliamentary praxis and promoted participatory democracy, but eventually became part of the political establishment tell us about the character of West German democracy? Differently put, is the "long march through the institutions" of grassroots activists-cum-Green politicians a story of democratic renewal, or of the disassembling of a workable parliamentary democracy in the name of individual interests? Contemporary criticisms of democratic praxis throughout the West raise the question of how institutions can be developed to reconcile the strong emotional commitment of a minority with the apathetic disinterest of an electoral majority? ${ }^{61}$ The sudden rise of the Pirates and the Alternative for Germany as new parties might serve as evidence of a further unraveling of collective politics, or perhaps a sign that serious deficits remain in developing a new sense of cyber-democracy. These difficult questions will require further consideration of the meaning of democratic participation and its relationship to the Greens' environmental project in contemporary society. 
Stephen Milder is Assistant Professor of Politics and Society in the Department of European Languages and Cultures at the University of Groningen. He received his $\mathrm{PhD}$ at the University of North Carolina in 2012 and has previously taught at Duke and Rutgers. He is currently completing a monograph entitled Greening Democracy: The Antinuclear Movement and Political Environmentalism in Western Europe, 1968-1983.

KonRad H. Jarausch is Lurcy Professor of European Civilization at the University of North Carolina at Chapel Hill and Senior Fellow of the Zentrum für Zeithistorische Forschung in Potsdam (Germany). He received his $\mathrm{PhD}$ at the University of Wisconsin-Madison in 1969 and has taught at the University of Missouri in Columbia, the Universität des Saarlands, Göttingen University, Potsdam University, and the Free University of Berlin. He has written or edited about forty books on German and European history, most recently Out of Ashes: A New History of Europe in the Twentieth Century (Princeton, 2015).

\section{Notes}

1. Infratest dimap, "Sonntagsfrage-Bundesweit;" available at http://www.infratest-dimap.de/ umfragen-analysen/bundesweit/sonntagsfrage/, accessed 31 January 2014.

2. Danny Michelsen and Franz Walter, Unpolitische Demokratie. Zur Krise der Repräsentation (Berlin, 2013), 10.

3. Wolfgang Streeck, Gekaufte Zeit. Die vertagte Krise des demokratischen Kapitalismus (Berlin, 2013), 10, 254.

4. Ingolfur Blühdorn, Post-Ecologist Politics: Social Theory and the Abdication of the Ecologist Paradigm (London, 2000).

5. Eva Kolinsky, The Greens In West Germany: Organization and Policy Making (Oxford, 1989).

6. Timoth Garton Ash defines the "history of the present" as a combination of the "crafts of historian and journalist" equivalent to a "historically minded witness" of contemporary events. Timothy Garton Ash, The History of the Present: Essays, Sketches, and Dispatches from Europe in the 1990s (New York, 1999), xii-xiii. See also Martin Sabrow, Die Zeit der Zeitgeschichte (Göttingen, 2012).

7. Konrad H. Jarausch, Matthias Middell, and Martin Sabrow, "Störfall DDR-Geschichtswissenschaft. Problemfelder einer kritischen Historisierung" in Die DDR-Geschichtswissenschaft als Forschungsproblem, Beiheft 27 of Historische Zeitschrift, ed. Georg G. Iggers and Konrad H. Jarausch (Munich, 1998).

8. The essays are drawn from the revised papers of a workshop held at the University of North Carolina and Duke University in the spring of 2013, marking the thirtieth anniversary of the Green Party's entry into the FRG parliament.

9. Lilian Klotzsch and Richard Stöss, "Die Grünen" in Parteien Handbuch. Die Parteien der Bundesrepublik Deutschland, 1945-1980, ed. Richard Stöss (Opladen, 1984) II: 1509-1599; Anna Hallensleben, Von der Grünen Liste zur Grünen Partei? Die Entwicklung der Grünen Liste Umweltschutz von ihrer Entstehung in Niedersachsen 1977 bis zur Gründung der Partei DIE GRÜNEN 1980 (Göttingen, 1984).

10. Herbert Kitschelt, The Logics of Party Formation: Ecological Politics in Belgium and West Germany (Ithaca, 1989). 
11. Andrei Markovits and Philip Gorski, The German Left: Red, Green, and Beyond (Oxford, 1993).

12. Markovits has further developed this interpretation of the post 1968 Left in recent lectures and publications. See, for example: Andrei S. Markovits and Katherine N. Crosby, From Property to Family: American Dog Rescue and the Discourse of Compassion (Ann Arbor, 2014), 1-30.

13. Margit Mayer and John Ely, The German Greens: Paradox Between Movement and Party (Philadelphia, 1998).

14. Perhaps because the PDS is not included in this diagram, the Greens are therefore by far the furthest left party according to Raschke. Joachim Raschke, Die Grünen. Wie sie wurden, was sie sind (Cologne, 1993), 48-49.

15. Ludwig Greven, "Sieben gute Gründe für Schwarz-Grün," Die Zeit (26 April 2013); and "Özdemir will die FDP überflüssig machen," Die Welt, 17 November 2013.

16. Silke Mende, "Weder rechts, noch links, sondern vorn." Eine Geschichte der Gründungsgrünen (Munich, 2011).

17. Paul Hockenos, Joschka Fischer and the Making of the Berlin Republic (Oxford, 2007).

18. Edgar Wolfrum, Rot-Grün an der Macht. Deutschland 1998-2005 (Munich, 2013), 42-50, 708-713.

19. Ulrich Herbert, Geschichte Deutschlands im 20. Jahrhundert (Munich, 2014), 984-986, 9961002.

20. Frank Bösch and Jens Giesecke, "Getrennt und vereint: Der Wandel des Politischen in Ost und West," unpublished manuscript (Potsdam 2014).

21. Niall Ferguson, "Introduction: Crisis, What Crisis? The 1970s and the Shock of the Global" in The Shock of the Global: The 1970s in Perspective, ed. Niall Ferguson et al. (Cambridge, 2010), 18. This is also the approach to the 1970s taken by Konrad Jarausch in "Verkannter Strukturwandel. Die siebziger Jahre als Probleme der Gegenwart" in Das Ende der Zuversicht: Die siebziger Jahre als Geschichte, ed. Konrad Jarausch (Göttingen, 2008), 9-28.

22. Jarausch differentiates "hard and soft caesuras" by comparing the type of break caused by "events like war, revolution, and terror attacks," which "allow themselves to be fixed to a certain year, date, or even hour" with "economic, social, and cultural change" which "usually occurs step-by-step over a long time period.” Jarausch (see note 21), 11. See also Frank Bösch, "Umbrüche in die Gegenwart. Globale Ereignisse und Krisenreaktionen um 1979," Zeithistorische Forschungen 9, no. 1 (2012): 8-32.

23. Anselm Döring-Manteuffel and Lutz Raphael, Nach dem Boom. Perspektiven auf die Zeitgeschichte seit 1970 (Göttingen, 2008).

24. The idea of the postindustrial society was first articulated by Alain Touraine in The PostIndustrial Society: Tomorrow's Social History: Classes, Conflicts and Culture in the Programmed Society, trans. Leonard F. X. Mayhew (New York, 1971), originally published in French, 1969. Daniel Bell popularized the concept in the United States with his The Coming of Post-Industrial Society: A Venture in Social Forecasting (New York, 1973).

25. Touraine (see note 24), 5-7.

26. Peter Stearns has long advocated the idea of a third phase of the industrial revolution rather than the emergence of postindustrial society. See, for example Peter N. Stearns, "The Idea of Postindustrial Society: Some Problems," Journal of Social History 17, no. 4 (1984): 685-693.

27. Daniel Bell, The End of Ideology: On the Exhaustion of Political Ideas in the Fifties (New York, 1962).

28. Belinda Davis, "What's Left? Popular Political Participation in Postwar Europe," American Historical Review 113, no. 2 (2008): 363.

29. Ibid., 370 .

30. Geoff Eley, Forging Democracy: The History of the Left in Europe, 1850-2000 (Oxford, 2002).

31. Samuel Moyn, The Last Utopia: Human Rights in History (Cambridge, 2010), 175. 
32. See, for example Joachim Jachnow, "What's Become of the German Greens?" New Left Review 81 (2013): 95-117.

33. Michael Bess, The Light-Green Society: Ecology and Technological Modernity in France, 19602000 (Chicago, 2003).

34. J.R. McNeill, "The Environment, Environmentalism, and International Society in the Long 1970s" in Ferguson et al (see note 21), 278.

35. Frank Uekötter, "Ökologische Verflechtungen: Umrisse einer grünen Zeitgeschichte," unpublished manuscript (Birmingham, 2014).

36. Markovits and Gorski (see note 11), 30.

37. On "lifestyle" activists, see, for example Timothy Brown, West Germany and the Global Sixties: The Anti-Authoritarian Revolt, 1962-1978 (New York, 2013). On the K-Groups, see Gerd Koenen, Das Rote Jahrzehnt. Unsere kleine deutsche Kulturrevolution, 1967-1977 (Cologne, 2001).

38. Jeremy Varon, Bringing the War Home: The Weather Underground, the Red Army Faction, and Political Violence in the Sixties and Seventies (Berkeley, 2004); Karrin Hanshew, Terror and Democracy in West Germany (Cambridge, 2012).

39. Stephen Milder, "Today the Fish, Tomorrow Us: Anti-Nuclear Activism in the Rhine Valley and Beyond, 1970-1979," PhD dissertation (Chapel Hill, 2012).

40. Sarah Summers, "Reconciling Family and Work: The West German Gendered Division of Labor and Women's Emancipation, 1960s to 1980s," PhD dissertation (Chapel Hill, 2012).

41. Mende (see note 16), passim.

42. Stephen Milder, "Thinking Globally, Acting (Trans-)Locally: Petra Kelly and the Transnational Roots of West German Green Politics," Central European History, 43 (2010): 301-326.

43. Friederike Brühöfener, "Defining the West German Soldier: Military, Masculinity and Society in West Germany, 1945-1989," PhD dissertation (Chapel Hill, 2014). See also Ute Frevert, Emotions in History: Lost and Found (Budapest, 2011).

44. Holger Nehring, Politics of Security: British and West German Protest Movements and the Early Cold War, 1945-1970 (Oxford, 2014).

45. “'Was heißt schon unregierbar?' Spiegel Gespräch mit dem Grünen Vorsitzenden Rainer Trampert über Nachrüstung, Atomkraft und das Verhältnis zur SPD," Der Spiegel, 21 February $1983,40$.

46. Steve Breyman, Why Movements Matter: The West German Peace Movement and U.S. Arms Control Policy (Albany, 2001), 150.

47. See, for example Günter Bannas, "Den anderen immer ähnlicher. Die Grünen verhalten sich wie den herkömmlichen Parteien," Frankfurter Allgemeine Zeitung, 15 August 1983, 3.

48. Karrin Hanshew similarly argues that engaging in dialogue with government officials over terrorism incorporated leftists into the democratic order and caused them to consider it defensible during the 1970s. Hanshew (see note 38), $240 \mathrm{ff}$.

49. Wolfrum (see note 18), 708ff.

50. See, for example, Joachim Raschke, Krise der Grünen. Bilanz und Neubeginn (Marburg, 1993).

51. See, for example Jutta Ditfuth, Krieg, Atom, Armut. Was sie reden, was sie tun: Die Grünen (Berlin, 2011).

52. Andrei S. Markovits and Joseph Klaver, Thirty Years of Bundestag Presence: A Tally of the Greens' Impact on the Federal Republic of Germany's Political Life and Public Culture, American Institute of Contemporary German Studies (Washington, 2012). A condensed version of this essay is included in the present collection.

53. Colin Crouch, Post-Democracy (London, 2004), 57-58.

54. Andreas Wirsching, Abschied vom Provisorium (Munich, 2006).

55. Fitzhugh Brundage and Konrad H. Jarausch, "Mass Politics" in The United States and Germany in the Twentieth Century: Conflict and Convergence, ed. Christof Mauch and Kiran Klaus Patel (New York, 2010).

56. Christiane Lemke and Gary Marks, ed., The Crisis of Socialism in Europe (Durham, 1992). 
57. For a more systematic development of this theme see Konrad H. Jarausch, Out of Ashes: A New History of Europe in the 20th Century (Princeton, 2015).

58. Martin Klimke, The Other Alliance: Student Protest in West Germany and the United States in the Global Sixties (Princeton, 2010); Quinn Slobodian, Foreign Front: Third World Politics in Sixties West Germany (Durham, 2012); and Brown (see note 37), passim.

59. One such exception is Christof Mauch, Nathan Stoltzfus, and Douglas R. Weiner, Shades of Green: Environmental Activism around the Globe (Lanham, 2006).

60. Regina Wick, Die Mauer muss weg-die DDR soll bleiben. Die Deutschlandpolitik der Grünen von 1979 bis 1990 (Stuttgart 2012).

61. Konrad H. Jarausch, After Hitler: Recivilizing Germans (New York, 2006), 151ff. See also Karl-Rudolf Korte, "Regierung unter schwindenden Gewissheiten. Substanzverluste und deren politische Herausforderungen in der Berliner Republik" in Die Berliner Republik. Beiträge zur deutschen Zeitgeschichte seit 1990, ed. Michael C. Bienert, Stefan Creuzberger, Kristina Hübner, and Matthias Oppermann (Berlin, 2013), 55-76. 